\title{
Sinensetin suppresses influenza a virus- triggered inflammation through inhibition of NF-KB and MAPKs signalings
}

\author{
Jiashun $\mathrm{Li}^{1 \dagger}$, Xiang Jie ${ }^{2+}$, Xiaoli Liang ${ }^{3 \dagger}$, Ziyu Chen ${ }^{4}$, Peifang Xie ${ }^{3}$, Xiping Pan ${ }^{5}$, Beixian Zhou ${ }^{6 *}$ and Jing $\mathrm{Li}^{3^{*}}$
}

\begin{abstract}
Background: Human respiratory system infected with influenza A virus (IAV) elicited a robust pro-inflammatory response that resulted in severe illness and even death. Currently, limited immunomodulator is available to counteract IAV-associated pneumonia in the clinic. Sinensetin, a polymethoxylated flavone with five methoxy groups, has been found to possess anti-agiogenesis, anti-inflammatory and anti-diabetic activities. However, the effects of sinensetin on IAV-triggered pro-inflammatory response remain unclear. In the present study, the antiinflammatory effects and corresponding possible mechanism of sinensetin in IAV-infected A549 cells were subjected to investigations.
\end{abstract}

Methods: The cytotoxic effects of sinensetin towards A549 cells was detected by MTT and LDH assays. The antiviral activity of sinensetin against influenza A virus was assayed in A549 cells with an engineered replication-competent influenza A virus carrying Gaussia luciferase reporter gene infection. The effect of sinensetin on influenza A virustriggered inflammatory reaction was determined by qRT-PCR, Luminex assays, ELISA and Western blot.

Results: Our results showed that sinensetin did not exhibit antiviral activity against A/PR/8/34 (H1N1). Meanwhile, sinensetin treatment significantly decreased IAV-induced expression of pro-inflammatory mediators at mRNA and protein levels, including IL-6, TNF- $a, I P-10$, IL-8 and MCP-1. Additionally, levels of cyclooxygenase (COX)-2 and the downstream product prostaglandin $\mathrm{E}_{2}\left(\mathrm{PGE}_{2}\right)$ up-regulated by IAV infection were dramatically suppressed by sinensetin. The mechanistic investigation revealed that sinensetin treatment suppressed the NFKB transcriptional activity using the NF-KB reporter stable HEK293 cell line stimulated with TNF-a $(20 \mathrm{ng} / \mathrm{mL})$ or influenza $\mathrm{H} 1 \mathrm{~N} 1$ virus. Furthermore, sinensetin abrogated influenza $\mathrm{H} 1 \mathrm{~N} 1$ virus-induced activation of NF-KB, ERK1/2 MAPK and p38 MAPK signalings.

Conclusion: Collectively, our results indicated that sinensetin has potential capacity to attenuate IAV-triggered pro-inflammatory response via inactivation of NF-KB, ERK1/2 MAPK and p38 MAPK signalings, which implied that sinensetin may be a promising candidate drug for influenza H1N1 virus infection therapeutics.

Keywords: Sinensetin, Influenza a virus, Anti-inflammatory, NF-KB, P38 MAPK, ERK1/2 MAPK

\footnotetext{
*Correspondence: lijinghenan@163.com; zbeixian@126.com

${ }^{\dagger}$ Jiashun Li, Xiang Jie and Xiaoli Liang contributed equally to this work.

${ }^{6}$ Department of Pharmacy, The People's hospital of Gaozhou, Gaozhou

525200, Guangdong, China

${ }^{3}$ State Key Laboratory of Respiratory Diseases, Guangzhou Institute of

Respiratory Health, National Clinical Centre of Respiratory Disease, The First

Affiliated Hospital, Guangzhou Medical University, Guangzhou, Guangdong

510120, P.R. China

Full list of author information is available at the end of the article
}

\section{$\triangle B M C$}

(c) The Author(s). 2020 Open Access This article is licensed under a Creative Commons Attribution 4.0 International License, which permits use, sharing, adaptation, distribution and reproduction in any medium or format, as long as you give appropriate credit to the original author(s) and the source, provide a link to the Creative Commons licence, and indicate if changes were made. The images or other third party material in this article are included in the article's Creative Commons licence, unless indicated otherwise in a credit line to the material. If material is not included in the article's Creative Commons licence and your intended use is not permitted by statutory regulation or exceeds the permitted use, you will need to obtain permission directly from the copyright holder. To view a copy of this licence, visit http://creativecommons.org/licenses/by/4.0/ The Creative Commons Public Domain Dedication waiver (http://creativecommons.org/publicdomain/zero/1.0/) applies to the data made available in this article, unless otherwise stated in a credit line to the data. 


\section{Background}

Annual seasonal influenza or occasional highly pathogenic avian influenza caused significant morbidity and mortality each year worldwide, especially among young children, the elderly, pregnant and immunocompromised individuals [1-4]. A modeling study estimated that influenza A virus infection causes approximately 300,000-650,000 seasonal influenza-associated respiratory deaths annually [5]. Due to viral genome reassorment or mutation, influenza infection was unmanageable with the current available medications including vaccination and anti-influenza agents (amantadine and oseltamivir) $[6,7]$.

Symptoms caused by viral infection varied from mild to severe, such as nasal obstruction, cough, headache, fever and even progression of acute respiratory distress syndrome (ARDS), which were closely related to respiratory tract inflammation $[8,9]$. It has been suggested that elevation of pro-inflammatory mediators such as IL-6 and TNF- $\alpha$ in local or systemic accounted for the symptom formation in human with seasonal influenza virus infection [10-12]. Uncontrolled cytokine production (termed "cytokine storm") in fatal cases of highly pathogenic $\mathrm{H} 5 \mathrm{~N} 1$ or $\mathrm{H} 7 \mathrm{~N} 9$ avian influenza virus infection has been found to be as the most common findings [13, 14]. The efficacy of corticosteroids treatment for influenza patients with pneumonia remained controversial. For example, in critically ill patients with severe influenza pneumonia, early combination oseltamivir and corticosteroids treatment seemed to confer a therapeutic benefit [15]. Conversely, retrospective studies revealed that corticosteroids treatment contributed to delay viral clearance and increase mortality in patients with H3N2 or 2009 H1N1 influenza virus infection [16, 17]. Therefore, corticosteroids were not recommended as routine drugs to treatment of patients with severe influenza pneumonia [18]. Based on these facts, development of novel immunomodulator or therapeutic approach for treatment of influenza pneumonia is an urgent clinical need.

Initiation of inflammatory reaction triggered by viral infection is dependent on several signaling cascades, including NF- $\mathrm{KB}$ and MAPKs (ERK1/2 and P38 MAPK). It's well-recognized that the interaction between virus-derived pathogen-associated molecular patterns (PAMPs) and cellular specialized pattern recognition receptors (PPRs) leads to $\mathrm{IKB} \alpha / \mathrm{NF}-\mathrm{kB}$ dissociation and thus released NF$\kappa B$ translocates into nucleus, where it regulates the transcription of pro-inflammatory mediators, including TNF$\alpha$, IL-6, IL-8 and COX-2 [19]. Recent studies in vitro and in vivo revealed that massive induction of proinflammatory mediators in $\mathrm{H} 5 \mathrm{~N} 1$-infected patients was NF-kB-dependent $[20,21]$. Furthermore, involvement of ERK1/2 and p38 MAPKs in the low or high pathogenic influenza-mediated dysregulation of pro-inflammatory cytokine expression has been reported [22, 23]. Therefore, these observations indicated that pharmacological inhibition of certain host cellular signaling associated with regulation of cytokine expression may act as a promising therapeutic strategy for the aberrant immune response induced by IAV.

Dietary intake of fruits rich in phytochemicals have been convincingly proved to have both nutritional and medicinal value, which provided potential beneficial effects for chemoprevention of various diseases, including influenza $[24,25]$. Bioactive ingredient from edible fruits and vegetables have gained immense interest for development of novel agents to treat influenza diseases due to the broad safety window [26, 27]. Based on the available information in the literature, the natural polymethoxyflavone compound sinensetin has been found abundantly in citrus peel $[28,29]$. Moreover, sinensetin was found to possess a number of pharmacological properties, including anti-inflammatory, anti-oxidative and anti-tumor [30-32]. Sinensetin has been reported to exert antiinflammatory effects via inhibition of NF- $\mathrm{BB}$ signaling [33]. However, the effect of sinensetin on IAV infection remains to be elucidated.

In the current study, we speculated that plant-derived sinensetin may be considered as potential functional food ingredients that provided promising health benefits, and thus exert protective effects against influenza diseases. As proof of principle, we set out to examine the anti-inflammatory effects of sinensetin on IAV-induced pro-inflammatory response in A549 human lung epithelial cells as well as the mechanism underlying the antiinflammatory effect of sinensetin on IAV infection.

\section{Methods \\ Reagents}

Sinensetin (Fig. 1a, Product No. S118322) was obtained from Aladdin Chemistry Co., Ltd. (Shanghai, China) (purity >98\%). Antibodies to P65, P38, ERK1/2, AKT, COX-2, GAPDH and phosphorylated form of P65, P38, ERK1/2 and AKT were from Cell Signaling Technology Inc. (Danvers, MA, USA). HRP-linked anti-rabbit secondary antibodies were purchased from EarthOx Life Science (Millbrae, CA, USA). BCA Protein Assay Kit for protein concentration quantification was purchased from Thermo Fisher Scientific Inc. (Walthman, MA, USA). The signal was detected using Enhanced chemiluminescence (ECL) reaction kit (Amersham Biosciences; Piscataway, NJ, USA). PrimeScript ${ }^{\mathrm{Tm}}$ RT Reagent kit and Premix Ex Taq ${ }^{\mathrm{Tm}}$ Reagent kit were obtained from Takara Bio, Inc. (Otsu, Japan).

\section{Cell lines, viruses and viral infections}

Human type II alveolar epithelial cell line (A549) and Madin-Darby Canine Kidney (MDCK) cells were 
obtained from ATCC, and maintained in RPMI-1640 medium (Gibco) and DMEM medium (Gibco), respectively, both supplemented with penicillin-streptomycin $(10 \mu \mathrm{L} / \mathrm{mL})$ and $10 \%(\mathrm{v} / \mathrm{v})$ heat-inactivated FBS in a humidified incubator with $5 \% \mathrm{CO}_{2}$.

Influenza virus $\mathrm{A} / \mathrm{PR} / 8 / 34$ (H1N1) used in present study was purchased from ATCC. The virus stocks were prepared in the allantoic cavities of embryonated chicken eggs and titrated on confluent MDCK cells in 96-well tissue culture plates.

For viral infection, A549 cells were inoculated with indicated multiplicities of infection (MOI) of viruses for $2 \mathrm{~h}$, and then replaced with serum-free RPMI-1640 medium containing various concentrations of sinensetin.

\section{Cytotoxicity assay}

The cytotoxicity of sinensetin on A549 cells was evaluated by MTT assay as described previously [34]. Briefly, A549 cells were cultivated into 96-well plates at a density of $5 \times 10^{4}$ cells per well for $12 \mathrm{~h}$ incubation, allowing cells to adhere. Then, the cells were incubated with various concentrations of sinensetin $(0-800 \mu \mathrm{g} / \mathrm{mL})$. After $48 \mathrm{~h}$ incubation, the culture medium was discared and washed twice with phosphate-buffered saline (PBS). $100 \mu \mathrm{L}$ of $0.5 \mathrm{mg} / \mathrm{mL}$ MTT solution (in DMEM medium) was added to each well and then incubated in dark for 4 h. Afterward, $150 \mu \mathrm{L}$ of dimethyl sulfoxide (DMSO) was added to dissolve the formed formazan crystals. The absorbance at $570 \mathrm{~nm}$ was measured using a microplate reader (Biotek, Vermont, USA).

For lactated hydrogenase (LDH) assay, A549 cells ( $5 \times$ $10^{4}$ cells $/ \mathrm{mL}, 100 \mu \mathrm{L}$ ) were incubated with various concentrations of sinensetin $(0-800 \mu \mathrm{g} / \mathrm{mL})$. Following $24 \mathrm{~h}$ incubation, culture supernatants were harvested and the released LDH was measured using an LDH cytotoxicity assay kit (Beyotime, Nantong, China) according to the manufacturer's protocol.

\section{Antiviral effect assay}

A549 cells at a final density of $5 \times 10^{4}$ cells per well were seeded into 96-well culture plates for $12 \mathrm{~h}$ incubation. Then, A549 cells were infected with $100 \mathrm{TCID}_{50}$ of IAVLuc, an engineered replication-competent influenza A virus carrying Gaussia luciferase reporter gene as reported before [35]. Two hours later, the culutute supernatants containing viral inoculum were discarded and then cells were incubated with indicated concentration of sinensetin. After $24 \mathrm{~h}$, cell culture supernatant was detected by adding with substrate of Coelenteron element and the signalings were assayed under the microplate Reader (Synergy HT, Bio-Tek, USA).

\section{Real-time RT-PCR}

A549 cells seeded in 6-well plates were infected with influenza virus $\mathrm{A} / \mathrm{PR} / 8 / 34(\mathrm{H} 1 \mathrm{~N} 1)(\mathrm{MOI}=0.1)$ for $2 \mathrm{~h}$, and then inoculum was discarded and replaced with fresh serum free medium containing $0-120 \mu \mathrm{g} / \mathrm{mL}$ of sinensetin for $24 \mathrm{~h}$. Total RNA was extracted from cells lysed in $1 \mathrm{~mL}$ of Trizol according to the manufacturers' instructions. The PrimeScript ${ }^{\text {Tw }}$ RT Reagent kit was employed to yield first-strand complementary DNA (cDNA) from $1 \mu \mathrm{g}$ of total RNA. Real-time quantitative PCR (qPCR) was performed to quantify the gene of interest with an Applied Biosystems 7500 system. Amplication conditions for qPCR were as follows: one cycle at $95^{\circ} \mathrm{C}$ for 10 $\mathrm{s}$, then followed by 40 cycles at $95^{\circ} \mathrm{C}$ for $5 \mathrm{~s}$ and $60^{\circ} \mathrm{C}$ for $40 \mathrm{~s}$. Sequence of primers and probes are listed in supplementary Table 1 . The $2^{-\triangle \Delta C T}$ method was employed to calculate relative target genes expression [36].

\section{Luminex}

After IAV-infected cells in the presence or absence of sinensetin $(0-120 \mu \mathrm{g} / \mathrm{mL})$ incubation for $24 \mathrm{~h}$, cell culture supernatants were harvested, centrifuged at 15000 $\mathrm{rpm}$ for $10 \mathrm{~min}$ at $4{ }^{\circ} \mathrm{C}$ to remove cellular debris, and stored at $-80^{\circ} \mathrm{C}$. Levels of cytokines in the supernatants were assayed by commercially available immunoassay kits (Millipore, Billerica, MA) according to the manufacturer's protocol.

\section{Measurement of $\mathrm{PGE}_{2}$}

The culture supernatants of IAV-infected cells in the presence or absence of sinensetin $(0-120 \mu \mathrm{g} / \mathrm{mL})$ were harvested at $24 \mathrm{~h}$, and levels of prostaglandin $\mathrm{E}_{2}\left(\mathrm{PGE}_{2}\right)$ were assayed by ELISA Kit (Invitrogen) according to the manufacturer's instructions.

\section{Western blotting}

Monolayers of A549 cells were grown to $80-90 \%$ confluency in 6-well plates (Guangzhou Jet Bio-Filtration Co., Ltd, TCP-010-006) and infected with influenza virus A/ $\mathrm{PR} / 8 / 34(\mathrm{H} 1 \mathrm{~N} 1)(\mathrm{MOI}=0.1)$ with different concentrations of sinensetin $(0-120 \mu \mathrm{g} / \mathrm{mL})$ treatment. After $24 \mathrm{~h}$, cells were lysed in ice-cold radio-immunoprecipitation (RIPA) buffer (Beyotime, China) containing $1 \mathrm{mM}$ phenylmethylsulphonylfluoride (PMSF) and protease inhibitors (SigmaAldrich; Merck, KGaA). Cellular lysates were centrifuged at $13,000 \mathrm{rpm}$ at $4{ }^{\circ} \mathrm{C}$ for $15 \mathrm{~min}$ and then quantification of protein concentration was measured using a BCA protein assay kit (Pierce; Thermo Fisher Scientific, Inc.). Equal amounts of samples $(20 \mu \mathrm{g})$ were electrophoresed by $10 \%$ SDS-PAGE and subsequently electro-transferred to PVDF membranes $(0.2 \mu \mathrm{m}$, Bio-Rad, USA). After blocking with $5 \%$ non-fat milk in $1 \times$ TBST $(0.1 \%$ Tween -20$)$ for $1 \mathrm{~h}$ at room temperature, membranes were incubated overnight at $4{ }^{\circ} \mathrm{C}$ with indicated antibodies against COX-2, P-P65, 
P65, P-ERK1/2, ERK1/2, P-P38, P38, P-AKT, AKT and GADPH. Next, membranes were probed with horseradish peroxidase (HRP)-conjugated secondary antibodies and protein bands were visualized using an enhanced chemiluminescence (ECL) reaction kit. Relative intensities of bands were quantified using imageJ software vesion 1.44P (National Institutes of Health, Bethesda, MD, USA).

\section{NF-KB reporter assay}

Monitoring of NF- $\mathrm{kB}$ activity is carried out based on reporter system as described previously [37]. Briefly, HEK293 (human embryonic kidney 293) cells, a stablyexpressed NF- $\mathrm{KB}$ luciferase reporter and an internal control eGFP plasmid, were grown into 96-well plate for overnight to allow for attachment. Then, cells were stimulated with TNF- $\alpha(20 \mathrm{ng} / \mathrm{mL})$ or infected with influenza virus $\mathrm{A} / \mathrm{PR} / 8 / 34(\mathrm{H} 1 \mathrm{~N} 1) \quad(\mathrm{MOI}=0.1)$ with or without sinensetin $(0-120 \mu \mathrm{g} / \mathrm{mL})$ treatment. After $24 \mathrm{~h}$ incubation, luciferase activity of cell lysates were measured using a luciferase assay kit (Promege). Luminescent signals were detected using a Synergy H1 Multi-Mode Reader (BioTek). The luciferase activities were normalized to parallel GFP intensities.

\section{Statistical analysis}

All data were expressed as the mean \pm standard error of the mean (SEM), and comparisons between different groups were performed by using one-way ANOVA analysis followed by Newman-Student-Keuls tests. $P$ values less than 0.05 was considered statistically significant.

\section{Results}

\section{Cytotoxicity effects of sinensetin on A549 cells}

To avoid undesired biological effects caused by cytotoxic doses of sinensetin, we firstly carried out MTT assay to investigate the non-cytotoxic concentration range of sinensetin on A549 cells. As shown in Fig. 1b, sinensetin had no cytotoxicity on A549 cells at the concentration up to $400 \mu \mathrm{g} / \mathrm{mL}$. Meanwhile, LDH assay showed that sinensetin did not lead to induce LDH release from A549 cells at the concentration up to $400 \mu \mathrm{g} / \mathrm{mL}$ (Fig. 1c), which suggested that sinensetin did not cause damage of plasma membrane. Therefore, we chose $120 \mu \mathrm{g} /$ $\mathrm{mL}$ of sinensetin as the maximum dose for the further experiments.

\section{Effects of sinensetin on influenza a virus-induced expression of pro-inflammatory mediators}

Utilizing IAV carrying Gaussia luciferase reporter gene, we found that sinensetin did not exhibit antiviral activity against A/PR/8/34 (H1N1) (Fig. 2a). Besides, aberrant immune responses characterized by excessive proinflammatory mediator production or immunocytes recruitment could cause severe influenza illness [13, 38]. Therefore, we investigated effects of sinensetin on influenza A virus-mediated upregulation of pro-inflammatory mediators expression at mRNA and protein levels. At $24 \mathrm{~h}$ post-infection (p.i.), influenza virus A/PR/8/34 (H1N1) infection dramatically increased mRNA levels for pro-inflammatory mediators including IL-6, IP-10, TNF- $\alpha$, IL- 8 and MCP- 1 , while sinensetin treatment significantly reduced the expression of these cytokines and chemokines (Fig. 2b). Consistent with these results, influenza virus $\mathrm{A} / \mathrm{PR} / 8 / 34$ (H1N1) -induced elevated secretion of IL-6, IP-10, TNF- $\alpha$, IL-8 and MCP-1 in the culture supernatant was reversed by sinensetin treatment (Fig. 2c). These results indicated that sinensetin has the capacity to attenuate influenza virus-induced pro-inflammatory response.

\section{Effects of sinensetin on the production of influenza a virus-induced $\mathrm{COX}-2$ and $\mathrm{PGE}_{2}$}

Besides the cytokines and chemokines, lipid mediators such as $\mathrm{PGE}_{2}$ also played a critical pathogenic role

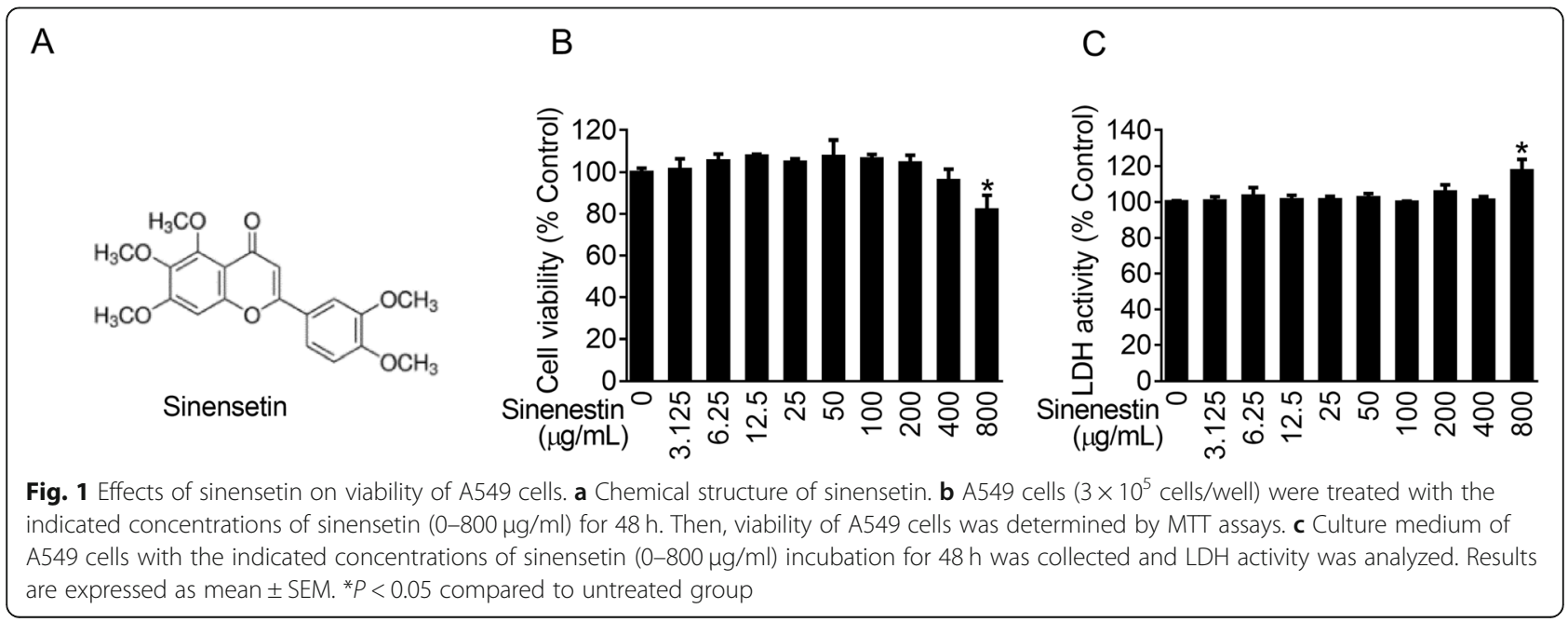


A
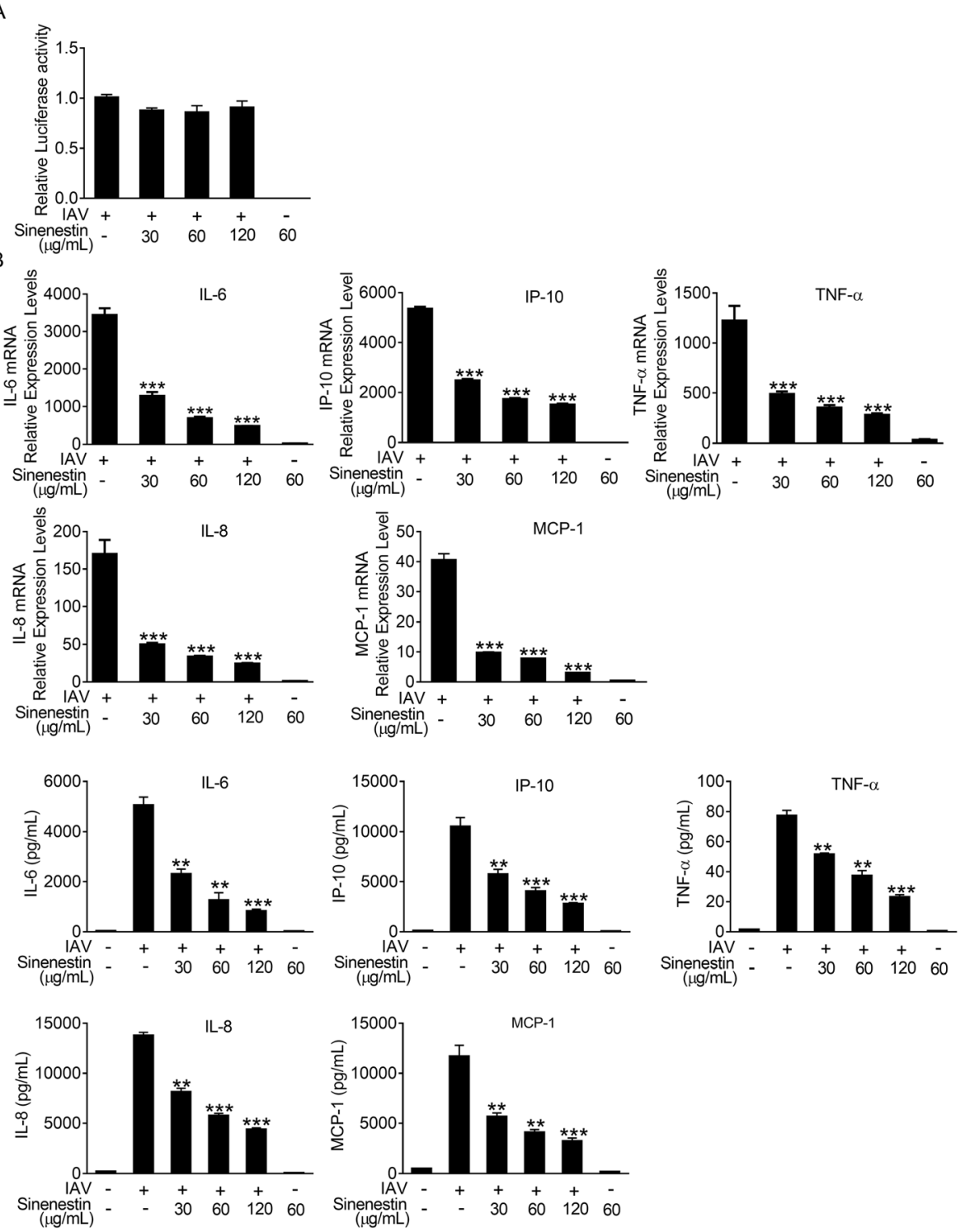

Fig. 2 Sinensetin inhibited influenza A virus-induced expression of cytokines and chemokines in A549 cells. a Influenza A virus carrying Gaussia luciferase reporter was used for determination of the antiviral effects of sinensetin. $\mathbf{b}$-c $A 549$ cells were infected with $\mathrm{A} / \mathrm{PR} / 8 / 34(\mathrm{H} 1 \mathrm{~N} 1)(\mathrm{MOI}=$ 0.1) with or without sinensetin treatment for $24 \mathrm{~h}$. The mRNA and protein levels of IL-6, IP-10, TNF-a, IL-8 and MCP-1 was determined by qRT-PCR (b) and Luminex (c). Data are expressed as mean \pm SEM of three independent experiments. ${ }^{* P}<0.05,{ }^{* *} P<0.01,{ }^{* * *} P<0.001$ compared to influenza virus-infected alone

during the influenza diseases [39]. Therefore, we carried out experiments to determine whether sinensetin treatment affected influenza virus-induced expression of lipid mediators. As expected, sinensetin treatment inhibited influenza A virus-induced both mRNA and protein expression levels of COX-2 in a dose-dependent manner (Fig. 3a, b). Parallel with these results, increased levels of cyclooxygenase (COX)-2 derived prostaglandin $\mathrm{E}_{2}\left(\mathrm{PGE}_{2}\right)$ by influenza virus infection were suppressed by sinensetin treatment (Fig. 3d). These data suggested that sinensetin was able to suppress influenza A virus-induced COX-2 expression and $\mathrm{PGE}_{2}$ production.

Effects of sinensetin on the activation of NF-KB and MAPK signalings in influenza a virus-infected A549 cells

IAV-mediated host cellular signaling pathways activation have been believed to be responsible for excessive proinflammatory mediator production [40]. To reveal the mechanism underlying the inhibitory effects of sinensetin on influenza virus-induced pro-inflammatory reaction, we 

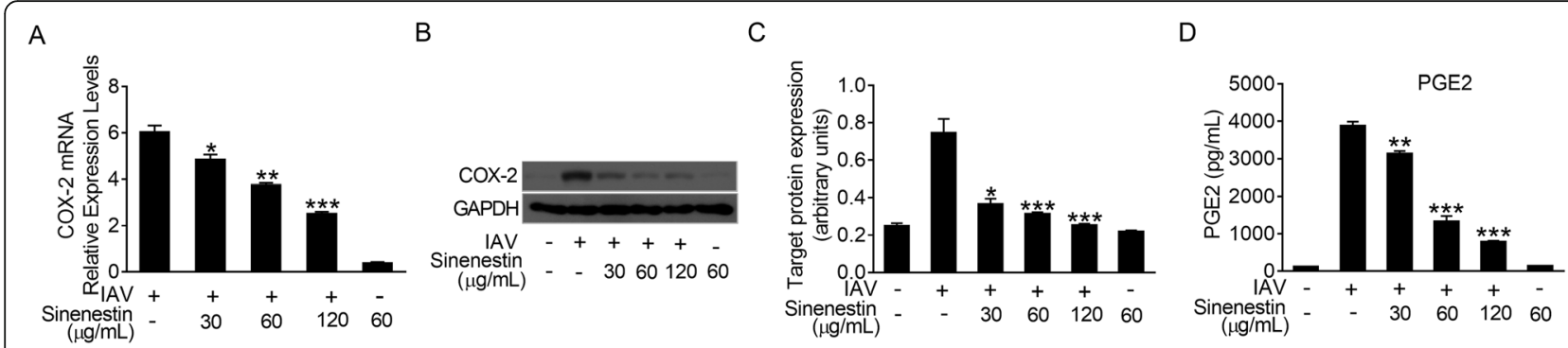

Fig. 3 Sinensetin inhibited influenza A virus-induced expression of COX-2 and PGE in A549 cells. Influenza virus A/PR/8/34 (H1N1) (MOI=0.1)

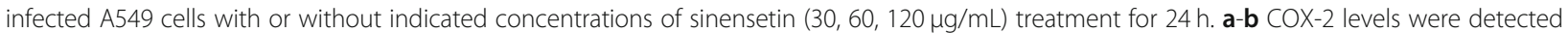
by qRT-PCR (a) and immunoblot analysis (b), respectively. c COX-2 expression was quantified using the imageJ software. $\mathbf{d}$ PGE 2 production in the culture supernatants was measured by ELISA. Data are expressed as mean \pm SEM of three independent experiments. ${ }^{*} P<0.05$, ${ }^{*} P<0.01,{ }^{* * *}$ $P<0.001$ compared to influenza virus-infected alone

investigated cellular signaling transduction affected by sinensetin during viral infection. Firstly, the NF- $k B$ reporter plasmid experiments showed that sinensetin treatment inhibited TNF- $\alpha$ or influenza virus A/PR/8/34 (H1N1) -stimulated activation of NF- $\mathrm{kB}$ (Fig. 4a, b). In accordance to that, immunoblot results confirmed that activation of NF- $\mathrm{B}$ triggered by viral infection was inhibited by sinensetin treatment (Fig. 4c). Similarly, sinensetin treatment significantly decreased the activation of ERK1/2 and p38 MAPK signalings, but not AKT signaling. Collectively, these results demonstrated that sinensetin exerted an antiinflammatory effect via blockade of NF-kB, ERK1/2 MAPK and p38 MAPK signalings.

\section{Discussion}

Although antiviral medications such as oseltamivir were prescribed for prophylaxis and prevention of seasonal or pandemic influenza virus infection in clinic, patients with these drugs seem to be less effective due to delayed initiation of therapy [41, 42]. Accumulating evidence suggested that the severe IAV infection, for the most part, could be provoked or exacerbated by the extent of inflammation in the respiratory system [8]. Interestingly, delayed concomitant treatment of neuraminidase inhibitor and immunomodulator resulted in a therapeutic benefit effect in mice infected lethal $\mathrm{H} 5 \mathrm{~N} 1$ influenza virus [43], which highlighted that the development of effective immunomodulatory agents is essential to attenuate the severity of the viral infection.

In previous study, sinensetin was found to have the potential to reduce LPS-mediated release of proinflammatory cytokines via inactivation of NF- $\mathrm{kB}$ pathway [33]. But the effects of sinensetin on IAV-induced inflammation has not been reported. Our study demonstrated that sinensetin treatment significantly decreased IAV-triggered up-regulation of pro-inflammatory mediators, including IL-6, IP-10, TNF- $\alpha$, IL-8, MCP-1, COX-2 and $\mathrm{PGE}_{2}$. Excessive production of pro-inflammatory mediators was considered as a hallmark of serious viral infectious diseases [44]. Increased IL-6 expression in patient with seasonal or pandemic influenza A H1N1 infection has been shown to be implicated in clinical symptom formation and illness severity [45]. Although TNF- $\alpha$ was documented for its role in antiviral immunity, it has pleiotropic properties that include stimulating other inflammatory mediator expression as well as disturbing the epithelial tight junction barrier, thus promoting development of ARDS [46-48]. In mice, studies demonstrated that deficiency in TNF- $\alpha$ signaling significantly improved highly virulent $\mathrm{H} 5 \mathrm{~N} 1$ virus-mediated excessive inflammation and high mortality [49]. Higher levels of chemokines, including IP10, IL- 8 and MCP-1, were believed to be associated with the acute respiratory distress syndrome (ARDS) progression and even fatal outcome in patients with $\mathrm{H} 5 \mathrm{~N} 1$ or H7N9 virus infection [14, 50]. Blockade of IP-10 and MCP-1 was proved to significantly lessen the disease severity of influenza virus infection [51, 52]. Expression of COX-2 and $\mathrm{PGE}_{2}$ has been suggested to play a role in enhancing virus-induced inflammation and impairment of host antiviral immunity $[39,53]$. Based on the above evidences, the inhibitory effect on these IAV-induced inflammatory mediators exerted by sinensetin might act as a promising strategy for treatment of influenza infectious diseases with excessive inflammation.

Host intracellular signaling activated by viral infection, such as NF-kB and MAPKs pathways, has been reported to be involved in the aberrant pro-inflammatory response associated with poor clinical outcome $[23,54]$. It has been shown that the induction of immune response-related genes in the highly pathogenic $\mathrm{H} 5 \mathrm{~N} 1$ virus infection was almost NF-kB-dependent [20]. It is believed that aberrant p38 MAPK activation is a critical driver for increased circulating levels of pro-inflammatory cytokine in patients with severe influenza [49]. Moreover, NF- $\mathrm{kB}$ and $\mathrm{p} 38$ MAPK signaling are involved in initiating expression of lipid mediators COX-2 and $\mathrm{PGE}_{2}[55,56]$. Therefore, 
A

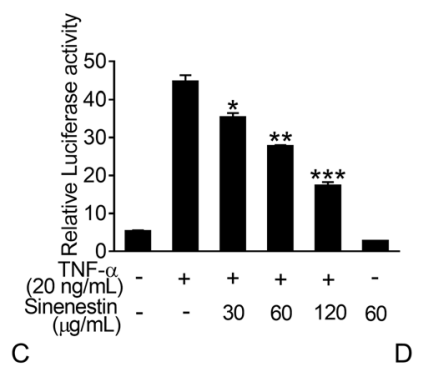

B

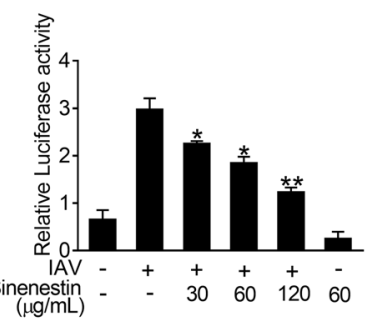

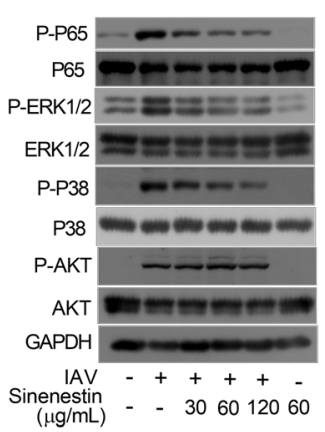
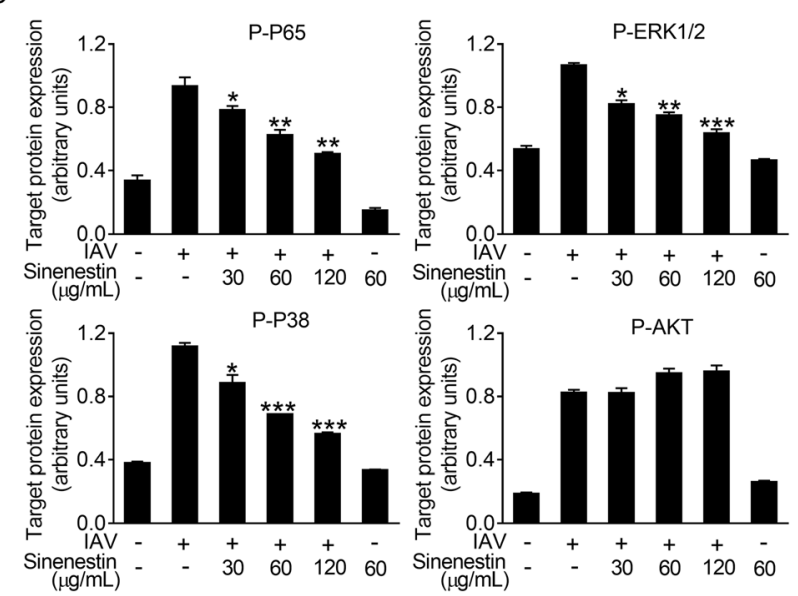

Fig. 4 Sinensetin inhibited influenza A virus-induced activation of NF-KB and MAPK signalings. a-b NF-KB reporter stable cell line HEK293 cells were stimulated with TNF-a $(20 \mathrm{ng} / \mathrm{mL})(\mathbf{a})$ or influenza virus A/PR/8/34 $(\mathrm{H} 1 \mathrm{~N} 1)(\mathrm{MOI}=0.1)(\mathbf{b})$ in the presence or in the absence of sinensetin $(0$, $30,60,120 \mu \mathrm{g} / \mathrm{mL}$ ). After $24 \mathrm{~h}$ incubation, cells were lysed for luciferase activity determination. c Immunoblot analysis of phosphorylated-P65, phosphorylated-ERK1/2, phosphorylated-P38 and phosphorylated-AKT in influenza virus A/PR/8/34 (H1N1)-infected A549 cells with or without sinensetin $(0,30,60,120 \mathrm{\mu g} / \mathrm{mL})$ treatment. GAPDH was used as internal control. $\mathbf{d}$ Indicated phosphorylated protein band intensities were quantified by ImageJ software. Data are expressed as mean \pm SEM of three independent experiments. ${ }^{*} P<0.05,{ }^{* *} P<0.01,{ }^{* * *} P<0.001$ compared to influenza virus-infected alone

targeting of these signalings may provide a potential therapeutic strategy for attenuating dysregulated inflammation in patients with severe influenza. Pharmacologic inhibition of NF- $k$ B, ERK1/2 MAPK and p38 MAPK decreased an array of proinflammatory mediators, including IL-6, IL-8, TNF- $\alpha$, MCP-1, COX-2 and PGE , and thus improved the outcome of influenza diseases [23, 57-60]. Our results showed that the polymethoxylated flavone sinensetin decreased IAV-mediated activation of NF-kB, ERK1/2 MAPK and p38 MAPK signalings. Therefore, it can be speculated that sinensetin exerted anti-inflammatory effect on IAV-mediated inflammation that may be due to its inhibitory action on these intracellular signaling cascades.

\section{Conclusions}

In conclusion, our data suggested that sinensetin attenuated IAV-induced pro-inflammatory cytokines and chemokines as well as lipid mediator, the mechanism of which is associated with the inhibition of IAV-mediated NF- $\mathrm{kB}, \mathrm{ERK} 1 / 2$ MAPK and p38 MAPK signalings. Therefore, sinensetin could hold promise for the therapeutics of influenza diseases with excessive inflammation.

\section{Supplementary information}

Supplementary information accompanies this paper at https://doi.org/10. 1186/s12906-020-02918-3.

Additional file 1: Table S1. Primers and Probe Sequences for qRT-PCR,

\section{Abbreviations}

COX-2: Cyclooxygenase-2; IAV: Influenza A virus; IL-6: interleukin 6; IL8: interleukin 8; IP-10: IFN-y-inducible IP-10; LDH: Lactate dehydrogenase; LPS: Lipopolysaccharide; MAPK: Mitogen-activated protein kinase; MCP1: Monocyte chemoattractant protein-1; MTT: 3-(4,5-dimethylthiazol-2-yl)-2,5diphenyl tetrazolium bromide; NF-kB: Nuclear factor-KB; PGE 2 : Prostaglandin E2; TNF-a: Tumor necrosis factor alpha

\section{Acknowledgements}

Not applicable.

\section{Authors' contributions}

$J L$ and BXZ designed the study. JSL, XJ and XLL collected and analysis the data. ZYC, PFX and XPP performed the statistical analysis. JL and BXZ wrote and revised the manuscript. The authors read and approved the final manuscript.

\section{Funding}

This work was supported by grants from the Natural Science Foundation of Guangdong Province, China (Grant no. 2018A030310172), the Secondary Development Projects of Guangdong Famous and Excellent Traditional 
Chinese Patent Medicines (Grant no. 20174005), the First Affiliated Hospital of Guangzhou Medical University (Grant no. LJ2016), the China Postdoctoral Science Foundation (Grant no. 2019 M652987) and Guangdong Basic and Applied Basic Research Foundation (Grant no. 2020A1515010720). The funders had no role in study design, data collection and analysis, decision to publish, or preparation of the manuscript.

\section{Availability of data and materials}

The datasets used and/o $r$ analyzed during the current study is available from the corresponding author on reasonable request.

\section{Ethics approval and consent to participate}

Not applicable.

\section{Consent for publication}

Not applicable.

\section{Competing interests}

The authors declare that they have no competing interests.

\section{Author details}

'Department of Respiratory, Affiliated Huadu Hospital, Southern Medical University (People's Hospital of Huadu District), Huadu, Guangzhou, Guangdong 510800, P.R. China. 'Huizhou third people's hospital, Guangzhou Medical University, Guangdong 516002, China. ${ }^{3}$ State Key Laboratory of Respiratory Diseases, Guangzhou Institute of Respiratory Health, National Clinical Centre of Respiratory Disease, The First Affiliated Hospital, Guangzhou Medical University, Guangzhou, Guangdong 510120, P.R. China. ${ }^{4}$ Institute of Respiratory Diseases, Department of Respiratory, The Affiliated Hospital of Guangdong Medical University, Zhanjiang 524001, China. ${ }^{5}$ Institute of Chinese Integrative Medicine, Guangzhou Medical University, Guangzhou, Guangdong 511436, P.R. China. 'Department of Pharmacy, The People's hospital of Gaozhou, Gaozhou 525200, Guangdong, China.

\section{Received: 7 July 2019 Accepted: 7 April 2020}

Published online: 05 May 2020

\section{References}

1. Poehling KA, Edwards KM, Weinberg GA, Szilagyi P, Staat MA, Iwane MK, Bridges CB, Grijalva CG, Zhu Y, Bernstein DI, et al. The underrecognized burden of influenza in young children. N Engl J Med. 2006;355(1):31-40.

2. Talbot HK. Influenza in Older Adults. Infect Dis Clin N Am. 2017;31(4):757-66.

3. Siston AM, Rasmussen SA, Honein MA, Fry AM, Seib K, Callaghan WM, Louie J, Doyle TJ, Crockett M, Lynfield R, et al. Pandemic 2009 influenza a(H1N1) virus illness among pregnant women in the United States. Jama. 2010; 303(15):1517-25.

4. Fraaij PL, Schutten M, Javouhey E, Burleigh L, Outlaw R, Kumar D, Boucher CA. Viral shedding and susceptibility to oseltamivir in hospitalized immunocompromised patients with influenza in the influenza resistance information study (IRIS). Antivir Ther. 2015;20(6):633-42.

5. Iuliano AD, Roguski KM, Chang HH, Muscatello DJ, Palekar R, Tempia S, Cohen C, Gran JM, Schanzer D, Cowling BJ, et al. Estimates of global seasonal influenza-associated respiratory mortality: a modelling study. Lancet (London, England). 2018;391(10127):1285-300.

6. Hayden $F G$, de Jong MD. Emerging influenza antiviral resistance threats. J Infect Dis. 2011;203(1):6-10.

7. Hai R, Schmolke M, Leyva-Grado VH, Thangavel RR, Margine I, Jaffe EL, Krammer F, Solorzano A, Garcia-Sastre A, Palese P, et al. Influenza a(H7N9) virus gains neuraminidase inhibitor resistance without loss of in vivo virulence or transmissibility. Nat Commun. 2013;4:2854.

8. Liu Q, Zhou YH, Yang ZQ. The cytokine storm of severe influenza and development of immunomodulatory therapy. Cell Mol Immunol. 2016; 13(1):3-10.

9. Hagau N, Slavcovici A, Gonganau DN, Oltean S, Dirzu DS, Brezoszki ES, Maxim M, Ciuce C, Mlesnite M, Gavrus RL, et al. Clinical aspects and cytokine response in severe $\mathrm{H} 1 \mathrm{~N} 1$ influenza A virus infection. Crit Care (London, England). 2010;14(6):R203.

10. Liu S, Yan R, Chen B, Pan Q, Chen Y, Hong J, Zhang L, Liu W, Wang S, Chen JL. Influenza virus-induced robust expression of SOCS3 contributes to excessive production of IL-6. Front Immunol. 2019;10:1843.
11. Betakova T, Kostrabova A, Lachova V, Turianova L. Cytokines induced during influenza virus infection. Curr Pharm Des. 2017;23(18):2616-22.

12. Kaiser L, Fritz RS, Straus SE, Gubareva L, Hayden FG. Symptom pathogenesis during acute influenza: interleukin- 6 and other cytokine responses. J Med Virol. 2001;64(3):262-8.

13. de Jong MD, Simmons CP, Thanh TT, Hien VM, Smith GJ, Chau TN, Hoang DM, Chau NV, Khanh TH, Dong VC, et al. Fatal outcome of human influenza a $(\mathrm{H} 5 \mathrm{~N} 1)$ is associated with high viral load and hypercytokinemia. Nat Med. 2006;12(10):1203-7.

14. Guo J, Huang F, Liu J, Chen Y, Wang W, Cao B, Zou Z, Liu S, Pan J, Bao C, et al. The serum profile of Hypercytokinemia factors identified in H7N9infected patients can predict fatal outcomes. Sci Rep. 2015;5:10942.

15. Kudo K, Takasaki J, Manabe T, Uryu H, Yamada R, Kuroda E, Kobayashi N, Matsushita T. Systemic corticosteroids and early administration of antiviral agents for pneumonia with acute wheezing due to influenza a(H1N1)pdm09 in Japan. PLoS One. 2012;7(2):e32280.

16. Brun-Buisson C, Richard JC, Mercat A, Thiebaut AC, Brochard L. Early corticosteroids in severe influenza a/H1N1 pneumonia and acute respiratory distress syndrome. Am J Respir Crit Care Med. 2011;183(9):1200-6.

17. Kim SH, Hong SB, Yun SC, Choi WI, Ahn JJ, Lee YJ, Lee HB, Lim CM, Koh Y. Corticosteroid treatment in critically ill patients with pandemic influenza a/ H1N1 2009 infection: analytic strategy using propensity scores. Am J Respir Crit Care Med. 2011;183(9):1207-14.

18. WHO. WHO Guidelines for Pharmacological Management of Pandemic Influenza A(H1N1) 2009 and Other Influenza Viruses. Geneva: World Health Organization; 2010.

19. Dai $X$, Zhang L, Hong T. Host cellular signaling induced by influenza virus. Sci China Life Sci. 2011;54(1):68-74

20. Schmolke M, Viemann D, Roth J, Ludwig S. Essential impact of NF-kappaB signaling on the H5N1 influenza a virus-induced transcriptome. J Immunol. 2009;183(8):5180-9.

21. Droebner K, Reiling SJ, Planz O. Role of hypercytokinemia in NF-kappaB p50-deficient mice after H5N1 influenza a virus infection. J Virol. 2008; 82(22):11461-6.

22. Borgeling Y, Schmolke M, Viemann D, Nordhoff C, Roth J, Ludwig S. Inhibition of p38 mitogen-activated protein kinase impairs influenza virusinduced primary and secondary host gene responses and protects mice from lethal H5N1 infection. J Biol Chem. 2014;289(1):13-27.

23. Pinto R, Herold S, Cakarova L, Hoegner K, Lohmeyer J, Planz O, Pleschka S. Inhibition of influenza virus-induced NF-kappaB and Raf/MEK/ERK activation can reduce both virus titers and cytokine expression simultaneously in vitro and in vivo. Antivir Res. 2011;92(1):45-56.

24. Lv X, Zhao S, Ning Z, Zeng H, Shu Y, Tao O, Xiao C, Lu C, Liu Y. Citrus fruits as a treasure trove of active natural metabolites that potentially provide benefits for human health. Chem Central J. 2015:9:68.

25. Zhang L, Cheng YX, Liu AL, Wang HD, Wang YL, Du GH. Antioxidant, antiinflammatory and anti-influenza properties of components from Chaenomeles speciosa. Molecules. 2010;15(11):8507-17.

26. Martin JH, Crotty S, Warren P, Nelson PN. Does an apple a day keep the doctor away because a phytoestrogen a day keeps the virus at bay? A review of the anti-viral properties of phytoestrogens. Phytochemistry. 2007; 68(3):266-74.

27. Sawai R, Kuroda K, Shibata T, Gomyou R, Osawa K, Shimizu K. Antiinfluenza virus activity of Chaenomeles sinensis. J Ethnopharmacol. 2008;118(1):108-12.

28. Nakanishi M, Hino M, Yoshimura M, Amakura $Y$, Nomoto $H$. Identification of sinensetin and nobiletin as major antitrypanosomal factors in a citrus cultivar. Exp Parasitol. 2019;200:24-9.

29. Zhang H, Tian G, Zhao C, Han Y. Characterization of polymethoxyflavone demethylation during drying processes of citrus peels. Food Funct. 2019; 10(9):5707-17.

30. Laavola M, Nieminen R, Yam MF, Sadikun A, Asmawi MZ, Basir R, Welling J, Vapaatalo H, Korhonen R, Moilanen E. Flavonoids eupatorin and sinensetin present in Orthosiphon stamineus leaves inhibit inflammatory gene expression and STAT1 activation. Planta Med. 2012;78(8):779-86.

31. Lam IK, Alex D, Wang YH, Liu P, Liu AL, Du GH, Lee SM. In vitro and in vivo structure and activity relationship analysis of polymethoxylated flavonoids: identifying sinensetin as a novel antiangiogenesis agent. Mol Nutr Food Res. 2012;56(6):945-56

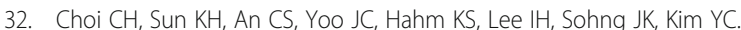
Reversal of P-glycoprotein-mediated multidrug resistance by $5,6,7,3^{\prime}, 4^{\prime}$ - 
pentamethoxyflavone (Sinensetin). Biochem Biophys Res Commun. 2002; 295(4):832-40.

33. Shin HS, Kang SI, Yoon SA, Ko HC, Kim SJ. Sinensetin attenuates LPSinduced inflammation by regulating the protein level of IkappaB-alpha. Biosci Biotechnol Biochem. 2012;76(4):847-9.

34. Zhou B, Liang X, Feng Q, Li J, Pan X, Xie P, Jiang Z, Yang Z. Ergosterol peroxide suppresses influenza a virus-induced pro-inflammatory response and apoptosis by blocking RIG-I signaling. Eur J Pharmacol. 2019;860: 172543.

35. Pan W, Dong Z, Li F, Meng W, Feng L, Niu X, Li C, Luo Q, Li Z, Sun C, et al. Visualizing influenza virus infection in living mice. Nat Commun. 2013;4:2369.

36. Livak KJ, Schmittgen TD. Analysis of relative gene expression data using real-time quantitative PCR and the 2(-Delta Delta $C(T))$ method. Methods. 2001;25(4):402-8

37. Li J, Zhou B, Li C, Chen Q, Wang Y, Li Z, Chen T, Yang C, Jiang Z, Zhong N, et al. Lariciresinol-4-O-beta-D-glucopyranoside from the root of Isatis indigotica inhibits influenza a virus-induced pro-inflammatory response. J Ethnopharmacol. 2015;174:379-86.

38. Kobasa D, Jones SM, Shinya K, Kash JC, Copps J, Ebihara H, Hatta Y, Kim JH, Halfmann P, Hatta M, et al. Aberrant innate immune response in lethal infection of macaques with the 1918 influenza virus. Nature. 2007:445(7125):319-23.

39. Coulombe F, Jaworska J, Verway M, Tzelepis F, Massoud A, Gillard J, Wong G, Kobinger G, Xing Z, Couture C, et al. Targeted prostaglandin E2 inhibition enhances antiviral immunity through induction of type I interferon and apoptosis in macrophages. Immunity. 2014;40(4):554-68.

40. Ludwig S, Planz O, Pleschka S, Wolff T. Influenza-virus-induced signaling cascades: targets for antiviral therapy? Trends Mol Med. 2003;9(2):46-52.

41. Kumar A. Early versus late oseltamivir treatment in severely ill patients with 2009 pandemic influenza a (H1N1): speed is life. J Antimicrob Chemother. 2011;66(5):959-63.

42. Beigel JH, Farrar J, Han AM, Hayden FG, Hyer R, de Jong MD, Lochindarat S, Nguyen TK, Nguyen TH, Tran TH, et al. Avian influenza a (H5N1) infection in humans. N Engl J Med. 2005;353(13):1374-85.

43. Zheng BJ, Chan KW, Lin YP, Zhao GY, Chan C, Zhang HJ, Chen HL, Wong SS, Lau SK, Woo PC, et al. Delayed antiviral plus immunomodulator treatment still reduces mortality in mice infected by high inoculum of influenza a/ H5N1 virus. Proc Natl Acad Sci U S A. 2008;105(23):8091-6.

44. Guo XJ, Thomas PG. New fronts emerge in the influenza cytokine storm Semin Immunopathol. 2017;39(5):541-50.

45. Chiaretti A, Pulitano S, Barone G, Ferrara P, Romano V, Capozzi D, Riccardi R. IL-1 beta and IL-6 upregulation in children with H1N1 influenza virus infection. Mediat Inflamm. 2013;2013:495848.

46. Seo SH, Webster RG. Tumor necrosis factor alpha exerts powerful antiinfluenza virus effects in lung epithelial cells. J Virol. 2002;76(3):1071-6

47. Rokkam D, Lafemina MJ, Lee JW, Matthay MA, Frank JA. Claudin-4 levels are associated with intact alveolar fluid clearance in human lungs. Am J Pathol. 2011;179(3):1081-7.

48. Yamauchi N, Harada T, Taniguchi F, Yoshida S, Iwabe T, Terakawa N. Tumor necrosis factor-alpha induced the release of interleukin-6 from endometriotic stromal cells by the nuclear factor-kappaB and mitogenactivated protein kinase pathways. Fertil Steril. 2004;82(Suppl 3):1023-8.

49. Perrone LA, Szretter KJ, Katz JM, Mizgerd JP, Tumpey TM. Mice lacking both TNF and IL-1 receptors exhibit reduced lung inflammation and delay in onset of death following infection with a highly virulent $\mathrm{H} 5 \mathrm{~N} 1$ virus. J Infect Dis. 2010;202(8):1161-70

50. Peiris JS, Yu WC, Leung CW, Cheung CY, Ng WF, Nicholls JM, Ng TK, Chan KH, Lai ST, Lim WL, et al. Re-emergence of fatal human influenza A subtype H5N1 disease. Lancet (London, England). 2004;363(9409):617-9.

51. Wang W, Yang P, Zhong Y, Zhao Z, Xing L, Zhao Y, Zou Z, Zhang Y, Li C, Li T, et al. Monoclonal antibody against CXCL-10/IP-10 ameliorates influenza a (H1N1) virus induced acute lung injury. Cell Res. 2013;23(4):577-80.

52. Wolf S, Johnson S, Perwitasari O, Mahalingam S, Tripp RA. Targeting the pro-inflammatory factor CCL2 (MCP-1) with Bindarit for influenza a (H7N9) treatment. Clin Transl Immunol. 2017;6(3):e135.

53. Lee SM, Cheung CY, Nicholls JM, Hui KP, Leung CY, Uiprasertkul M, Tipoe GL, Lau YL, Poon LL, Ip NY, et al. Hyperinduction of cyclooxygenase-2mediated proinflammatory cascade: a mechanism for the pathogenesis of avian influenza H5N1 infection. J Infect Dis. 2008;198(4):525-35.

54. Lee N, Wong CK, Chan PK, Lun SW, Lui G, Wong B, Hui DS, Lam CW, Cockram CS, Choi KW, et al. Hypercytokinemia and hyperactivation of phospho-p38 mitogen-activated protein kinase in severe human influenza a virus infection. Clin Infect Dis. 2007;45(6):723-31.

55. Mizumura K, Hashimoto S, Maruoka S, Gon Y, Kitamura N, Matsumoto K, Hayashi S, Shimizu K, Horie T. Role of mitogen-activated protein kinases in influenza virus induction of prostaglandin E2 from arachidonic acid in bronchial epithelial cells. Clin Exp Allergy. 2003;33(9):1244-51.

56. Singer CA, Baker K, McCaffrey A, AuCoin DP, Dechert MA, Gerthoffer WT. p38 MAPK and NF-kappaB mediate COX-2 expression in human airway myocytes. Am J Physiol Lung Cell Mol Physiol. 2003;285(5):L1087-98.

57. Li J, Liang X, Zhou B, Chen X, Xie P, Jiang H, Jiang Z, Yang Z, Pan X. (+)pinoresinolObetaDglucopyranoside from Eucommia ulmoides Oliver and its antiinflammatory and antiviral effects against influenza a ( $\mathrm{H} 1 \mathrm{~N} 1)$ virus infection. Mol Med Rep. 2019;19(1):563-72.

58. Carey MA, Bradbury JA, Rebolloso YD, Graves JP, Zeldin DC, Germolec DR. Pharmacologic inhibition of COX-1 and COX-2 in influenza a viral infection in mice. PLoS One. 2010;5(7):e11610.

59. Lee DC, Cheung CY, Law AH, Mok CK, Peiris M, Lau AS. p38 mitogenactivated protein kinase-dependent hyperinduction of tumor necrosis factor alpha expression in response to avian influenza virus H5N1. J Virol. 2005; 79(16):10147-54.

60. Hui KP, Lee SM, Cheung CY, Ng IH, Poon LL, Guan Y, Ip NY, Lau AS, Peiris JS Induction of proinflammatory cytokines in primary human macrophages by influenza a virus ( $\mathrm{H} 5 \mathrm{~N} 1)$ is selectively regulated by IFN regulatory factor 3 and p38 MAPK. J Immunol. 2009;182(2):1088-98.

\section{Publisher's Note}

Springer Nature remains neutral with regard to jurisdictional claims in published maps and institutional affiliations.

Ready to submit your research? Choose BMC and benefit from:

- fast, convenient online submission

- thorough peer review by experienced researchers in your field

- rapid publication on acceptance

- support for research data, including large and complex data types

- gold Open Access which fosters wider collaboration and increased citations

- maximum visibility for your research: over $100 \mathrm{M}$ website views per year

At BMC, research is always in progress.

Learn more biomedcentral.com/submissions 